\title{
Performance of three type of constructed wetland systems for treating municipal waste water
}

\author{
Jassim Hussein Abdullah Al-Maliky 1,*, Abdul-Hussain Yousif Al-Adhub ${ }^{2}$, Najah Abood Hussain ${ }^{3}$ \\ Dept. of Biological, College of Science, University of Basrah, Basrah, Iraq \\ *Corresponding Author: \\ Email: marshlands2014@gmail.com
}

\begin{abstract}
A pilot constructed wetland systems project was constructed during 2015 at the University of Basrah, Iraq. These systems are a vertical subsurface flow system (VSSF), a horizontal subsurface flow system (HSSF) and a surface flow system (SF). These systems were planted with Phragmites australis, Typha domingensis and Certophyllum demersum respectively. It had been operated during 2016 as separated systems. The results recorded a total mean of $78.98 \%$ of $\mathrm{NH}_{4}-\mathrm{N}$ removal efficiency with $78.68 \%$ by VSSF, $76.04 \%$ by HSSF and $82.20 \%$ by SF. This figure reached $90.58 \%$ removal of $\mathrm{PO}_{4}$, with 90.29 by VSSF, $90.18 \%$ by HSSF and 92.02 by SF. Also high level of total mean removal efficiency of $95.96 \%$ of BOD 5 , the results were $97.65 \%$ for VSSF, $97.99 \%$ for HSSF and $92.25 \%$ for SF. The results indicated that the system was highly effective at removing the target pollutants.
\end{abstract}

Keywords: Constructed wetland, Vertical subsurface, Horizontal subsurface, Surface flow.

\section{Introduction}

Since first developed, constructed wetlands and their significant benefits have been extensively considered and widely utilized for treating wastewater from a variety of sources such as domestic, industrial and mine waste waters. ${ }^{1,2}$ They have been effectively utilized for treating public wastewater. ${ }^{3}$ Also, they have been commonly used to polish the final discharge of wastewater from treatment plants. ${ }^{4}$

For many valid reasons, constructed wetlands could be the greatest mechanism for managing final wastewater treatment. ${ }^{5,6}$ Constructed wetlands are now one of the most internationally diffused technologies for the biological, physical and chemical processes that occur in natural wetland. This paper focuses on a practical attempt to understand and implement some constructed wetland systems for treating waste water in Iraqi's weather conditions.

\section{Materials and Methods}

The constructed wetland station was contained within two parallel lines of three systems - vertical subsurface flow system (VSSF) planted with Phragmites australis, a horizontal subsurface flow system (HSSF) planted with Typha domingensis and surface flow system (SF) planted with Certophyllum demersum. Systems were made from fiber glass with the following dimensions: $300 \mathrm{~cm}$ length, $120 \mathrm{~cm}$ width and $100 \mathrm{~cm}$ high. Also, three PVC lines were used to connect all the systems together Fig. 1 and Fig. 2.

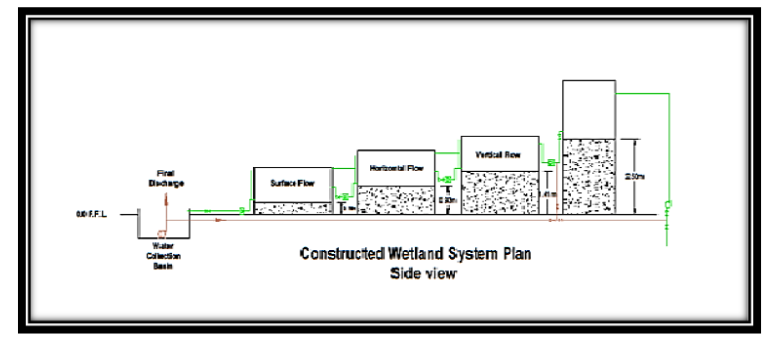

Fig. 1: Constructed wetland station (side view)

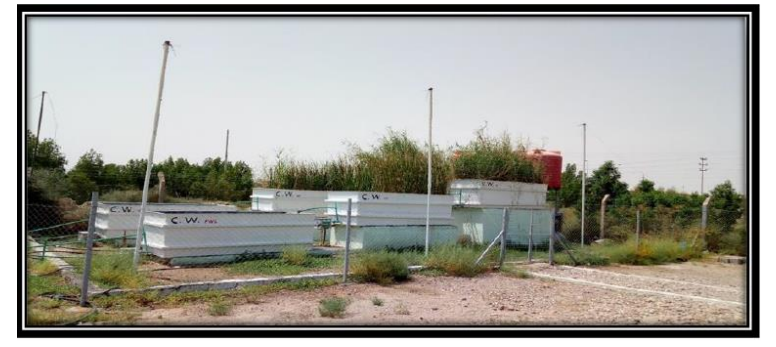

Fig. 2: Constructed wetland systems station at Basrah University

To test the systems separately, specific operation method was conducted, called "stable operation" whereby the systems operated during the first group of experiments during March, April and May. In this method, wastewater feeds into each system and remains for five days. Additionally, two levels of loading rate were used to test the system's volume ability for treating wastewater. These loading rates were $25 \%$ and $50 \%$ which equal to (162 and 324) L.

\section{Results and Discussion}

To evaluate the ability of a constructed wetland systems station in treating wastewater, some important parameters have been measured as the following: 
$\mathrm{BOD}_{5}$ with system type:

The results in (Fig. 3) indicated that the total mean and Std. deviation of $\mathrm{BOD}_{5}$ for the different systems, namely: HSSF, SF and VSSF were 1.05 $\pm 0.90,4.19 \pm 3.72$ and $1.23 \pm 0.94$, and these values were $50.71 \pm 10.68$ for SW and $2.40 \pm 0.321 .23 \pm 0.94$, for TW. The highest and lowest BOD5 levels were 11.33 and 0.10 which were recorded on day two at SF and on day three at HSSF respectively. Statistical analysis showed that there were no significant differences in $\mathrm{BOD}_{5}$ among retention time in day at $\mathrm{P} \leq 0.05$. The system type also showed no significant differences, the interaction between Retention Time * system type showed no significant differences at $\mathrm{P} \leq 0.05$.

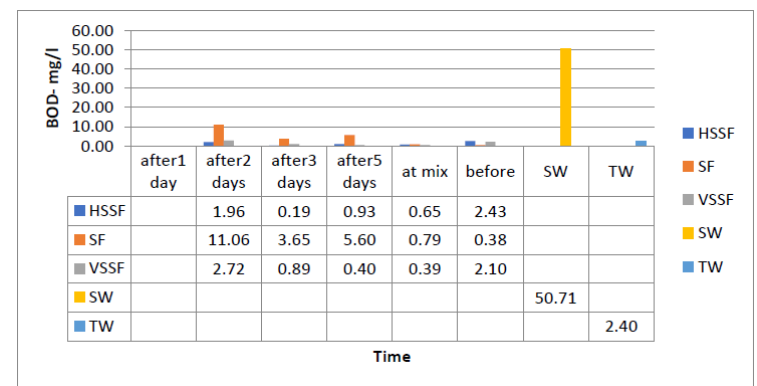

Fig. 3: BOD $_{5}$-with type of system in stable operation method

The removal efficiency of $\mathrm{BOD}_{5}$ after five days of treatment was $96.38 \%$, while the maximum and minimum removal efficiency was $99.45 \%$ and $91.05 \%$ respectively. This value reached more than $90 \%$ after the second day of treatment. In terms of each system's ability to remove $\mathrm{BOD}_{5}$, the results were $97.99 \%$ for HSSF, 97.65\% for VSSF and $92.25 \%$ for SF Fig. 4 and 5.

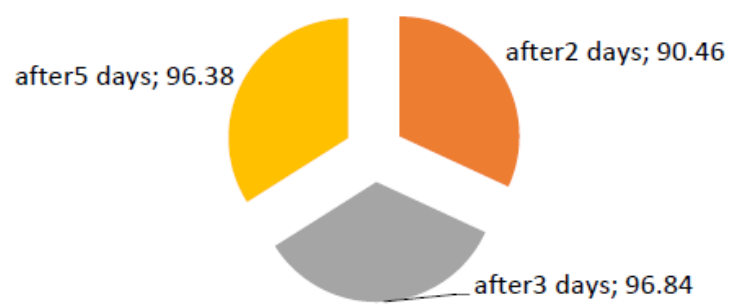

Fig. 4: $\mathrm{BOD}_{5}$ removal efficiency based on number of days

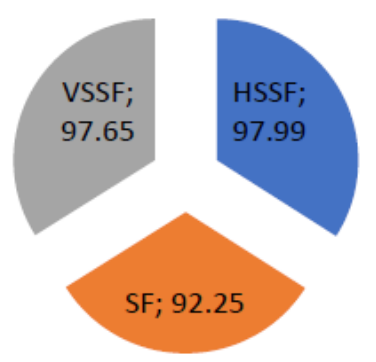

Fig. 5: $\mathrm{BOD}_{5}$ removal effciency with type of systems
BOD $_{5}$ with loading rate percentage: The results in (Fig. 6) showed the total mean and Std. deviation of $\mathrm{BOD}_{5}$ with different loading rate percentages which were $1.74 \pm 1.74$ for at a $25 \%$ loading rate and $2.68 \pm 3.47$ for at $50 \%$ loading rate. These levels were $50.71 \pm 10.68$ for $\mathrm{SW}$ and $2.40 \pm 0.32$ for TW. The highest $\mathrm{BOD}_{5}$ value was 11.33 , which was recorded within the SF system when the loading rate was $50 \%$, while the lowest $\mathrm{BOD}_{5}$ level was 0.10 which was recorded within the HSSF system when the loading rate was $25 \%$. Statistical analysis confirmed that there were no significant differences in $\mathrm{BOD}_{5}$ values between loading rate percentage at $\mathrm{P} \leq 0.05$.

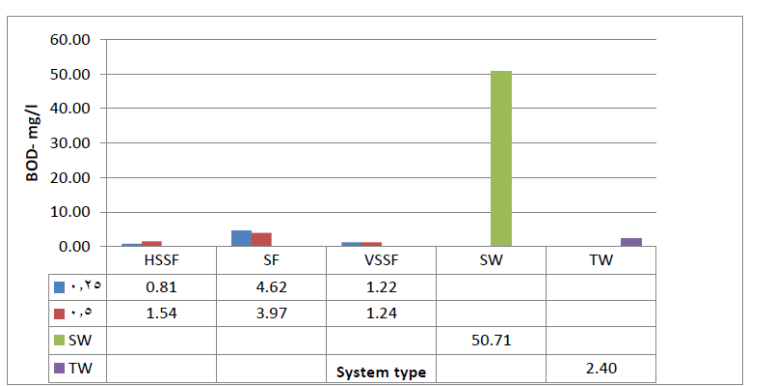

Fig. 6: $\mathrm{BOD}_{5}$-with the percentage of loading rate in stable operation method

The removal efficiency of $\mathrm{BOD}_{5}$ with both loading rate were $96.83 \%$ and $94.88 \%$ when the loading rates were $25 \%$ and $50 \%$ respectively (Fig. 7 ).
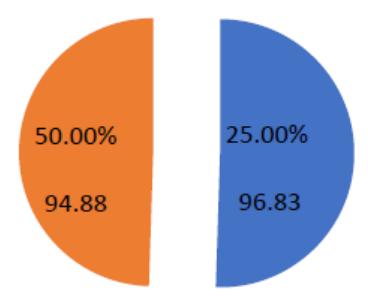

Fig. 7: $\mathrm{BOD}_{5}$ removal effciency with loading rate

All constructed wetland system showed an excellent capacity to reduce the $\mathrm{BOD}_{5}$ value to an accepted level in a very short time as clearly seen in Fig. 3. Generally, the statistical analysis indicated that there were no significant differences among single systems, which is in line with the findings of. ${ }^{7}$ Wastewater with $\mathrm{BOD}_{5}$ above $300 \mathrm{mg} / \mathrm{l}$ is considered to be strong, while a $\mathrm{BOD}_{5}$ of less than $100 \mathrm{mg} / \mathrm{l}$ is considered weak. In order to prevent reduction of DO in water bodies, it is necessary to remove oxygen-demanding materials in influent water.

Organic matter could be breakdown by aerobic bacteria which works to utilze oxygen and produce biomass and energy. On the other hand, $\mathrm{CH} 4$ can be produced by anaerobic bacteria. ${ }^{8}$ The results of this study achieved high removal efficiencies of $97.65 \%, 97.99 \%$ and $92.25 \%$ within the VSSF, VSSF and SF systems respectively as shown in Fig. 5. The results recorded a high level of $\mathrm{BOD}_{5}$ removal compared to many other 
previous studies. It was found by Olson et al. ${ }^{9}$ that removal efficiency of $\mathrm{BOD}_{5}$ was about $87 \%$ in integrated system of septic tank flowed by a SF-CW system in Egypt. The average of $10.5-9.9 \mathrm{mg} / \mathrm{l}$ was the final discharge of $\mathrm{BOD}_{5}$ after crossing planted beds in the Czech Republic's HSF-CW system, with an average removal efficiency of about $88 \% .{ }^{10}$ Also, $\mathrm{BOD}_{5}$ removal efficiency of $82 \%$ was achieved by ${ }^{11}$ throughout an average of three years' treatment using a VSSF-CW system. An example from Pakistan also showed effective $\mathrm{BOD}_{5}$ removal of about $75 \%$ after five days of treatment using a Phragmaties constructed wetland bed. ${ }^{12}$

The results give a clear picture showing the ability of these systems to significantly reduce the $\mathrm{BOD}_{5}$ level regardless of the high percentage of loading rate. In other words, even with a high loading rate of $50 \%$, the results in figure 7 showed that the removal efficiencies were $96.83 \%$ when the loading rate was $25 \%$, and this percentage was still very high sitting at about $94.88 \%$ when the loading rate was $50 \%$. This means the amount of feeding wastewater can be increased within the system even if it is up to the normal ability of these system for SW. This evidence also could provide a good indicator of constructed wetland systems' propensity for removing $\mathrm{BOD}_{5}$, especially in our environmental circumstances which can reduce the area required to design the constructed wetland system. For example, in China, a study compared seasonal variation of removal efficiency between cold and warm temperatures, where the results showed the following: $92 \%, 73 \%$ and $71 \%$ for COD, $\mathrm{BOD}_{5}$ and $\mathrm{NH}_{4}-\mathrm{N}$ at warmer temperatures, while it dropped to $85 \%, 40 \%$ and $20 \%$ during cold weather. ${ }^{13}$

$\mathbf{N H}_{4}-\mathbf{N}$ with system type: The results in (Fig. 8) illustrate a dramatic drop in the value of $\mathrm{NH}_{4}-\mathrm{N}$. The total mean and Std. deviation for each system was 4.20 \pm 2.89 for HSSF, $3.54 \pm 2.78$ for SF and $3.91 \pm 2.37$ for VSSF. These values were about $19.60 \pm 7.41$ for SW and $8.40 \pm 5.94$ for TW. Statistical analysis showed that there were significant differences in $\mathrm{NH}_{4}-\mathrm{N}$ values among retention time in days at $\mathrm{P} \leq 0.05$. There were no significant differences in $\mathrm{NH}_{4}-\mathrm{N}$ among system type. In addition to that, the interaction between Retention Time * system type showed no significant differences at $\mathrm{P} \leq$ 0.05 .

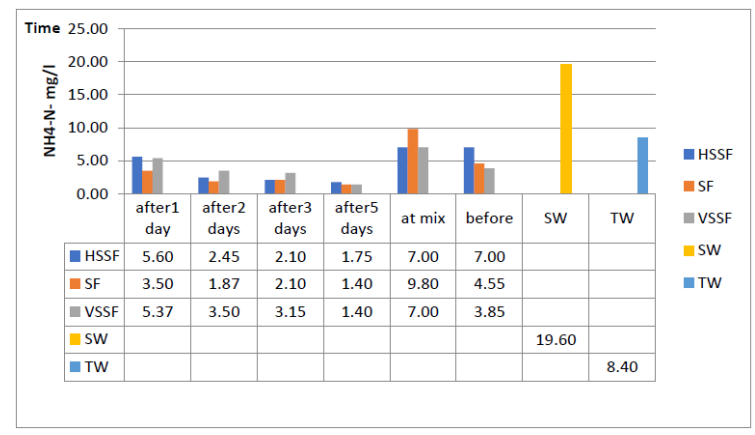

\section{Fig. 8: $\mathrm{NH}_{4}-\mathrm{N}$ with the type of system in stable} operation days

Removal efficiency of $\mathrm{NH}_{4}-\mathrm{N}$ was achieved at about $90.14 \%$ after five day of treatment, whereas $87.50 \%$ was removed after the second day of treatment. Also the total mean of removal efficiency was $76.04 \%, 82.20 \%$ and 78.68\% for HSSF, SF and VSSF respectively (Fig. 9 and $10)$.

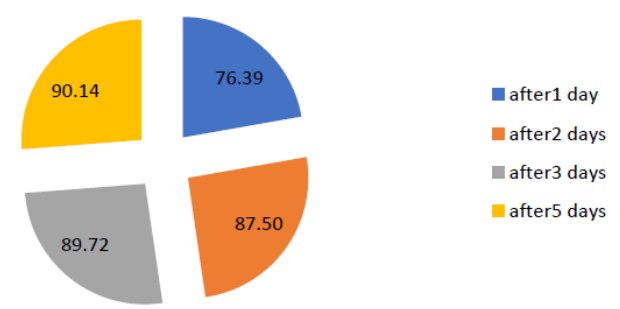

Fig. 9: $\mathrm{NH}_{4}-\mathrm{N}$ removal efficiency with time in days

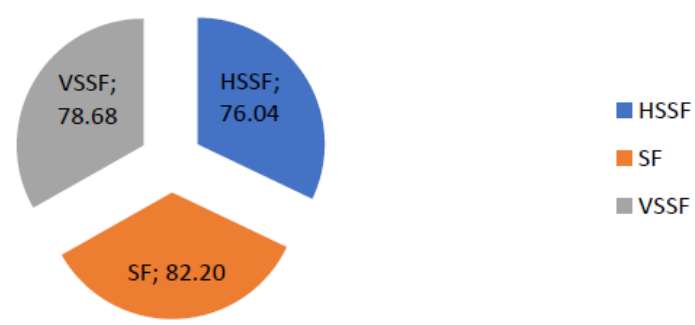

Fig. 10: $\mathrm{NH}_{4}-\mathrm{N}$ removal efficiency based on systems type

$\mathbf{N H}_{4}-\mathbf{N}$ with loading rate: The results in (Fig. 11) represented the relationship between the loading flow rate percentage and removal of $\mathrm{NH}_{4}-\mathrm{N}$. It shows that there was a high removal percentage of amonium when the loading flow rate was $25 \%$, and $50 \%$. The total mean and Std. deviation were $3.92 \pm 2.67 \mathrm{mg} / \mathrm{l}$ when the loading rate percentage was $25 \%$, and $2.80 \mathrm{mg} / \mathrm{l}$ when the loading rate percentage was $50 \%$. The maximum value was $28 \mathrm{mg} / \mathrm{l}$ for SW, while the minimum was $1.40 \mathrm{mg} / \mathrm{l}$ which was recorded at HSSF, SF and VSSF when the loading rate percentage was $25 \%$. Statistical analysis confirmed that there were no significant differences in $\mathrm{NH}_{4}-\mathrm{N}$ between loading rate percentage at $\mathrm{P} \leq 0.05$.

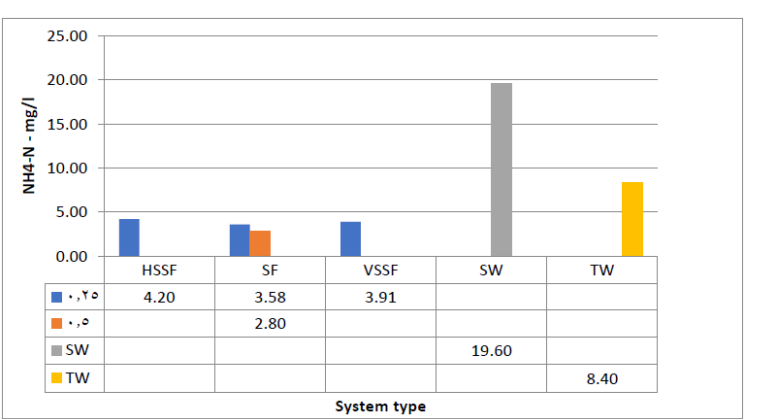

Fig. 11: $\mathrm{NH}_{4}$ with percentage of loading rate in stable operation method 
The removal efficiency for both loading rates, which were $25 \%$ and $50 \%$, were $77.22 \%$ and $98.33 \%$ (Fig. 12).

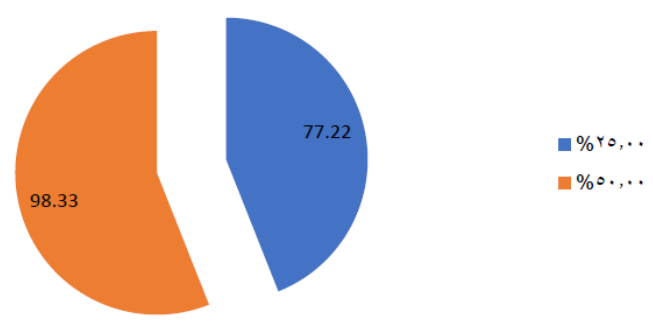

Fig. 12: $\mathrm{NH}_{4}-\mathrm{N}$ removal efficiency with loading rate

Fig. 8 indicated a gradual decline of $\mathrm{NH}_{4}-\mathrm{N}$ with time. On the fifth day, the removal efficiency for all systems reached about $90.14 \% .{ }^{9}$ Valipour and Ahn, 2016 pointed out that microorganisms continue to grow and utlize organic matter and nitorgen with expanded of hydraulic retention time. The system's performance recorded a high removal efficiency within the SF system with about $82.20 \%$ flowed by VSSF with about $78.68 \%$. The lowest removal efficiency was recorded within the HSSF system. As a result of its limited capacity to transfer oxygen, $\mathrm{HSSF}$ has less ability to oxidize $\mathrm{NH}_{3}-\mathrm{N}$ to NO3-N. ${ }^{14}$ In addition, the VSSF system is well-known for its ability to transfer oxygen due to intermittent feeding which adds advantage to this type of system and increases its removal efficiency. ${ }^{15}$ It has been reported that the SF constructed wetland systems have had high removal efficiency of organic compounds through settling and biological degredation. Also, some important processes such as nitrification, denitrification and ammonia volatilization take place especially under alkline circumstances. This high $\mathrm{pH}$ is a result of algal photosynthesis decay. ${ }^{16}$

The same trend of $\mathrm{NH}_{3}-\mathrm{N}$ removal efficiency results (about 96\%) have been achieved through using a gravelbased hybrid system constructed wetland to treat wastewater. ${ }^{17}$ Also, the performance of Will's Barn vertical flow constructed wetland recorded a high average decline of $\mathrm{NH}_{4}-\mathrm{N}$ from about $93.9 \mathrm{mg} / \mathrm{l}$ to 10.29 $\mathrm{mg} / \mathrm{l}$ in effluent treated water. ${ }^{18}$ In addition, high removal of TN-N and $\mathrm{NH}_{4}-\mathrm{N}$ was observed in the vertical flow system, whereas horizontal flow showed a high removal efficiency of COD compared with VSSF..$^{19}$ Moreover, after crosing the two stages of VSSF-CW, $\mathrm{NH}_{4}-\mathrm{N}$ sharply decreased from $38 \mathrm{mg} / \mathrm{l}$ to $7.3 \mathrm{mg} / \mathrm{l}$ after the first stage and to about $2 \mathrm{mg} / \mathrm{l}$ after the second stage of the constructed wetland. ${ }^{20}$

Aorthou-phosphate with system type: The results in (Fig. 13) illustrated that orthou-phosphate was declined in all system but in different levels. The total mean and Std. deviation for HSSF, SF and VSSF were as respect $2.39 \pm 2.84,2.02 \pm 3.98$ and $2.42 \pm 4.27 \mathrm{mg} / \mathrm{l}$ respectively. These values were $16.16 \pm 14.14$ and $1.01 \pm 1.23 \mathrm{mg} / \mathrm{l}$ for
SW and TW respectively. The maximum and minimum values were 26.86 and $0.03 \mathrm{mg} / \mathrm{l}$ for $\mathrm{SW}$ and VSSF during fifth day respectively. Statistical analysis confirmed that there were significant differences in orthou- $\mathrm{PO}_{4}$ between retention time in days at $\mathrm{P} \leq 0.05$. However, there were no significant differences in orthou- $\mathrm{PO}_{4}$ among system type at the same level. The interaction between system type and months also showed no significant differences in orthou- $\mathrm{PO}_{4}$ values.

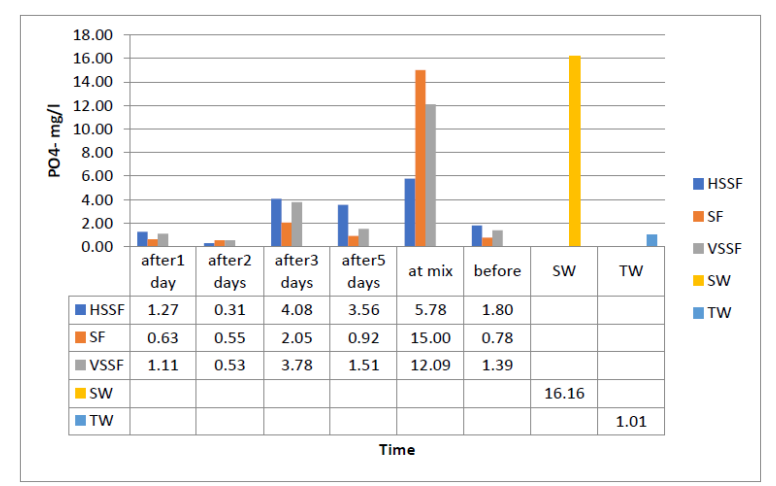

Fig. 13: $\mathrm{PO}_{4}$-with the type of system in stable operation method

Removal efficiency of $\mathrm{PO}_{4}$ after five days of treatment reached $92.56 \%$. Systems preformance of removal efficiency recorded high achievement in Sf with high percentage of $92.02 \%$ followed by $90.29 \%$ and 90.18\% for VSSF and HSSF respectively (Fig. 14 and $15)$.

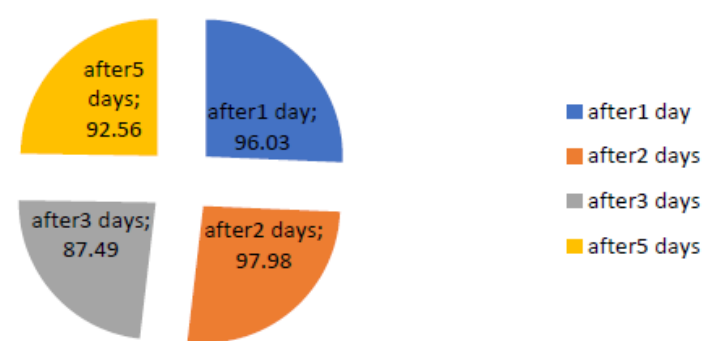

Fig. 14: $\mathrm{PO}_{4}$ removal efficiency with time in days in stable operation

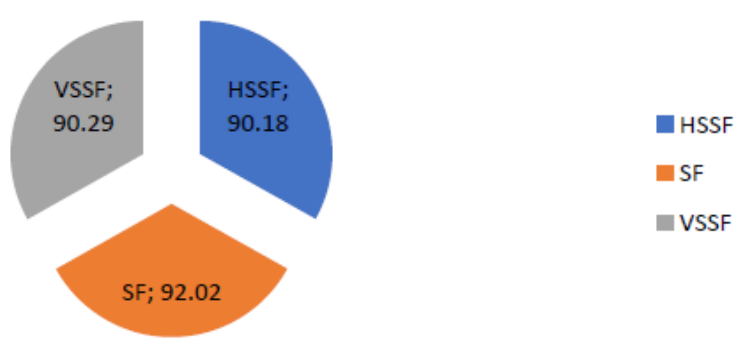

Fig. 15: $\mathrm{PO}_{4}$ removal efficiency with system type in stable operation

Orthou-phosphate with loading rate percentage: The results in (Fig. 16) showed that all systems removed 
approximately the same amount of $\mathrm{PO}_{4}$ during the feeding systems with $25 \%$ loading flow rate of sewage water. Also, SF removed high amount of $\mathrm{PO}_{4}$ even the loading rate was $50 \%$ other systems (including HSSF and VSSF) were not tasted with 50\% of loading rate. The total mean and Std. deviation of ortho- $\mathrm{PO}_{4}$ for both loading rate percentage $25 \%$ and $50 \%$ were $2.38 \pm 3.82$ and $0.87 \pm 0.30 \mathrm{mg} / \mathrm{l}$ respectively. The highest and lowest points recorded were 26.86 and $0.03 \mathrm{mg} / \mathrm{l}$ which were measured in SW and VSSF when the loading rate was $25 \%$. Statistical analysis showed that there were no significant differences in orthou- $\mathrm{PO}_{4}$ between loading rate percentage at $\mathrm{P} \leq 0.05$.

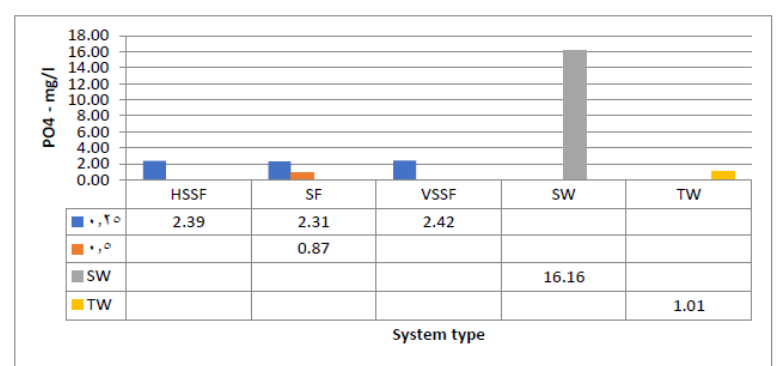

Fig. 16: $\mathrm{PO}_{4}$-with the percentage of loading rate in stable operation method

High removal efficiency of $\mathrm{PO}_{4}$ were achieved with both loading rate as the removal efficiency was $90.48 \%$ when the loading rate was $25 \%$ and the results were much better when the loading rate was $50 \%$ as it reached about $95.87 \%$; however, this result include measuring of $\mathrm{PO}_{4}$ for SF system only (Fig. 17).

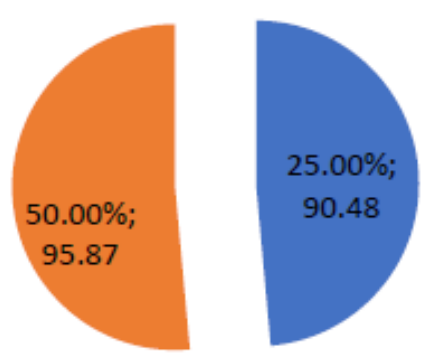

Fig. 17: $\mathrm{PO}_{4}$ removal efficiency with loading rate in stable operation

Results of this study achieved excellent results compared to many previous studies conducted in order to evaluate $\mathrm{PO}_{4}$ removal efficiency of constructed wetlands (Fig. $13 \&$ 14). While sewage water had a total mean of about $16 \mathrm{mg} / \mathrm{l}$ of $\mathrm{PO}_{4}$, this amount is removed to about $0.92,1.51$ and 3.56 in the SF, VSSF and HSSF systems respectively by the fifth day of experimentation. However, a clear decrease of $\mathrm{PO}_{4}$ was recorded after the first and second days of treatment. Also, it has been noticed that the systems had a similar ability to remove $\mathrm{PO}_{4}$ with the highest removal percentage achieved by
SF, followed by the VSSF and HSSF systems respectively.

$\mathrm{PO}_{4}$ is removed within a constructed wetland system by several mechanisms including adsorbtion, precipitation and plant uptake, which is considered temporal storage as the nutrients could be released to the aquatic environment after the plants have decayed. ${ }^{16}$ Phosphorus removal efficiency within constructed wetlands, as reported in many previous studies, significantly varied from 6-99\%, dependent primarily on wetland design, loading rate and environmental condition. ${ }^{21}$ As an example, the reduction of phophorus was about $66 \%$ in a lab-scale of constructed wetland. ${ }^{22}$

The results of removing $\mathrm{PO}_{4}$ within the SF system with that level of loading rate was higher compared with a $25 \%$ loading rate. As shown in figure (17), removal efficiency reached around $95.87 \%$ with a loading rate of $50 \%$, whereas the removal efficiency of $\mathrm{PO}_{4}$ was $90.48 \%$ when the loading rate was $25 \%$. A possible reason for this is the high growth of plant Certophyllum demersum within the SF system which could take more $\mathrm{PO}_{4}$ for its growth.

\section{Conclusion}

Overall it can be clearly indicated that, implementation of constructed wetland systems could be a valid solution for treating wastewater as all systems (VSSF, HSSF and SF) which have been implemented at this experiment showed an excellent result in order to remove a high percentage of the target pollutants.

\section{References}

1. Bialowiec, A., et al., The influence of plants on nitrogen removal from landfill leachate in discontinuous batch shallow constructed wetland with recirculating subsurface horizontal flow. Ecological engineering, 2012. 40:p. 4452.

2. Du, C., et al., Research progress on application of constructed wetland in wastewater treatment in China. Agricultural Science and Technology, 2014. 15(2):p.310.

3. Chena, b., Y., et al., Effects of plant biomass on bacterial community structure in constructed wetlands used for tertiary wastewater treatment. Ecological engineering, 2015. 84:p. 38-45.

4. Chen, Y., et al., Effects of cattail biomass on sulfate removal and carbon sources competition in subsurfaceflow constructed wetlands treating secondary effluent. Water research, 2014. 59:p. 1-10.

5. Kadlec and S.D. Wallace, Treatment wetlands 2nd edition. 2nd edition ed. 2009, Boca Raton, Florida: CRC Press.

6. Iridra, S. wetland for water pollution control. 2013 [cited 2016 19/10/2016].

7. Vymazal, J. and L. Kröpfelová, Wastewater Treatment in Constructed Wetlands with Horizontal Sub-Surface Flow. 2008, Czech Republic: Springer Science and Business Media B. V.

8. Lindeburg, M.R., Chemical Engineering Reference Manual for the PE Exam. 2012: www. ppi2pass.

9. Olson, J.J., et al., Biodegradation rates of separated diesel components. Environmental toxicology and chemistry, 1999. 18(11)(11): p. 2448-2453. 
10. Vymazal, J., Constructed wetlands for wastewater treatment. Water, 2010. 2(3): p. 530-549.

11. Stefanakis, A.I. and V.A. Tsihrintzis, Effects of loading, resting period, temperature, porous media, vegetation and aeration on performance of pilot-scale vertical flow constructed wetlands. Chemical Engineering Journal, 2012. 181: p. 416-430.

12. Haydar, S., et al., Proposed model for wastewater treatment in Lahore using constructed wetlands. JOURNAL OF FACULTY OF ENGINEERING \& TECHNOLOGY, 2015. 22(1): p. 9-19.

13. Peng, J.-F., B.-Z. Wang, and L. Wang, Multi-stage ponds-wetlands ecosystem for effective wastewater treatment. Journal of Zhejiang University. Science. B, 2005. 6(5): p. 346

14. Vymazal, J., Types of constructed wetlands for wastewater treatment: their potential for nutrient removal. Transformations of nutrients in natural and constructed wetlands, 2001: p. 1-93.

15. Cooper, P., M. Smith, and H. Maynard, The design and performance of a nitrifying vertical flow reed bed treatment system. Water Science and Technology, 1996. 35: p. 5.

16. Kadlec, R.H. and S.D. Wallace, Treatment wetlands. 2008, Boca Raton, Florida: CRC Press.

17. Melián, J.H., et al., Hybrid constructed wetlands for wastewater treatment and reuse in the Canary Islands. Ecological engineering, 2010. 36(7): p. 891-899.

18. Weedon, C., Compact vertical flow constructed wetland systems-first two years' performance. Water Science and Technology, 2003. 48(5): p. 15-23.

19. Kantawanichkul', S. and S. Wannasri, Wastewater treatment performances of horizontal and vertical subsurface flow constructed wetland systems in tropical climate. Songklanakarin Journal Science Technology, 2013. 35(5): p. 599-603.

20. Brix, H., C. Arias, and N. Johansen. BOD and nitrogen removal from municipal wastewater in an experimental two-stage vertical flow constructed wetland system with recycling. in Arusha, Tanzania, 16-19 september 2002. 2002.

21. Valipour, A. and Y.-H. Ahn, Constructed wetlands as sustainable ecotechnologies in decentralization practices: a review. Environmental Science and Pollution Research, 2016. 23(1): p. 180-197.

22. Zurita, F., J. de Anda, and M.A. Belmont, Performance of laboratory-scale wetlands planted with tropical ornamental plants to treat domestic wastewater. Water quality research journal of Canada, 2006. 41(4): p. 410417. 